\title{
Selected ${ }^{1} \mathrm{H}$-NMR and ${ }^{13} \mathrm{C}$-NMR
}
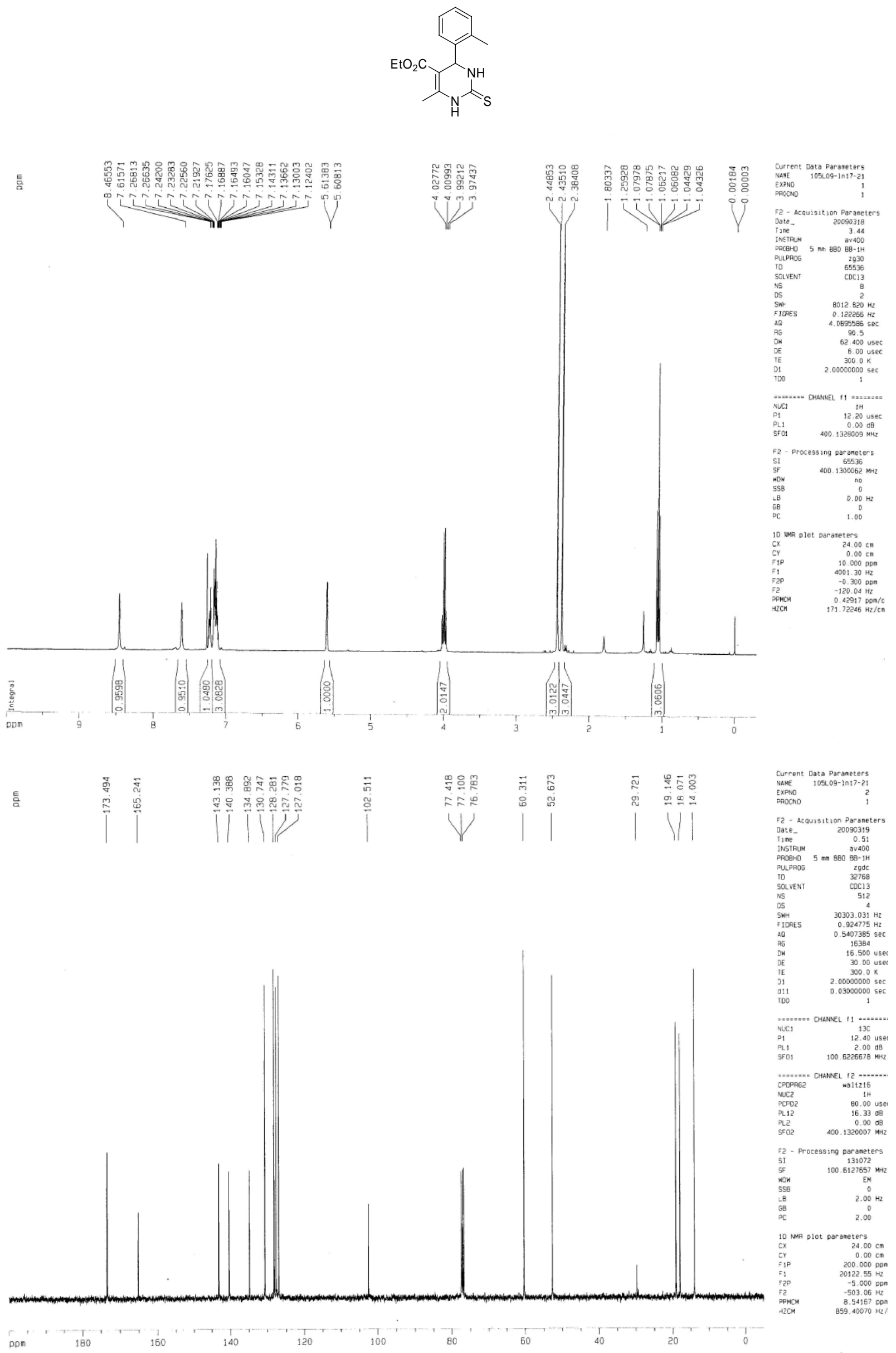

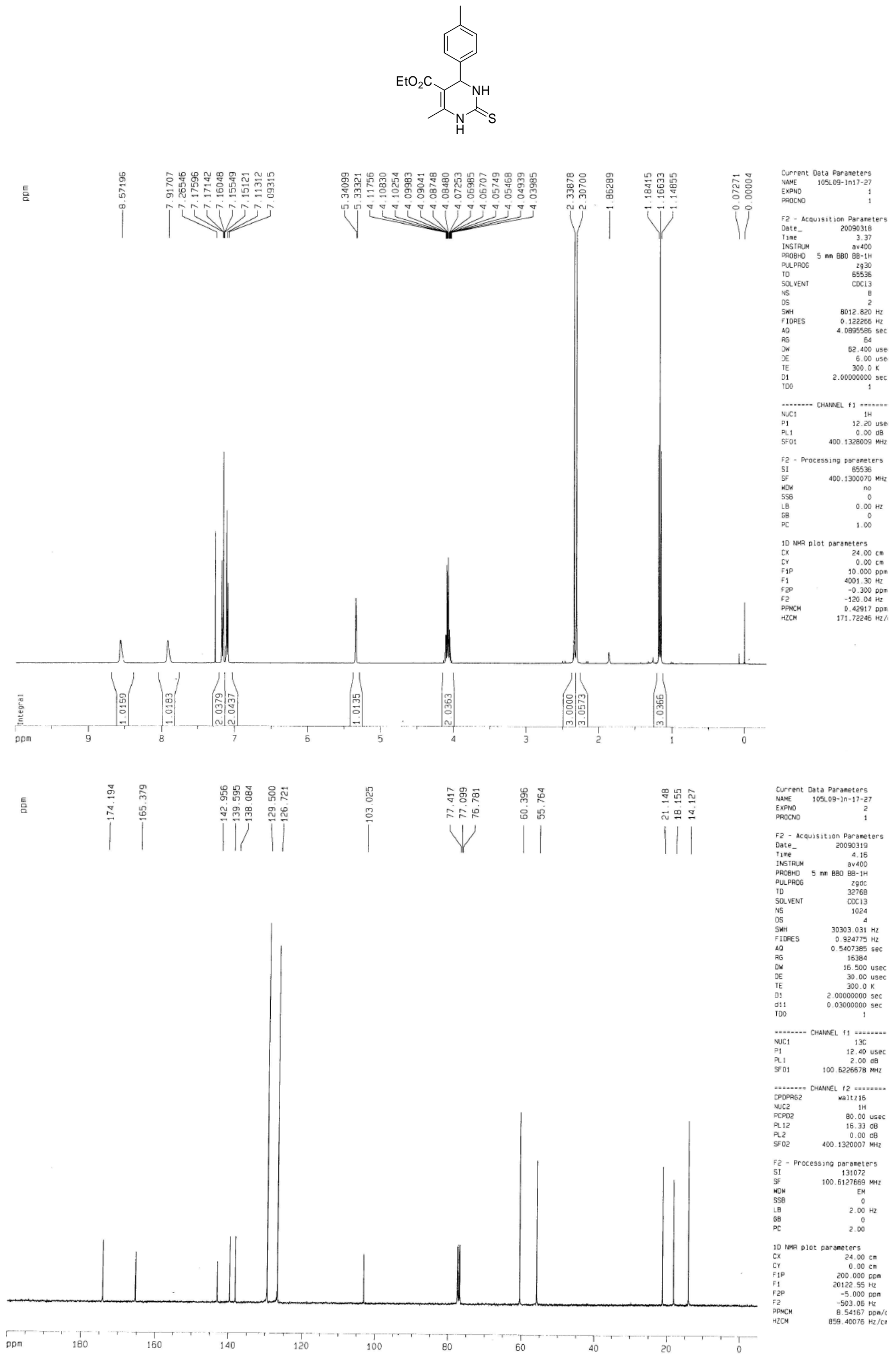


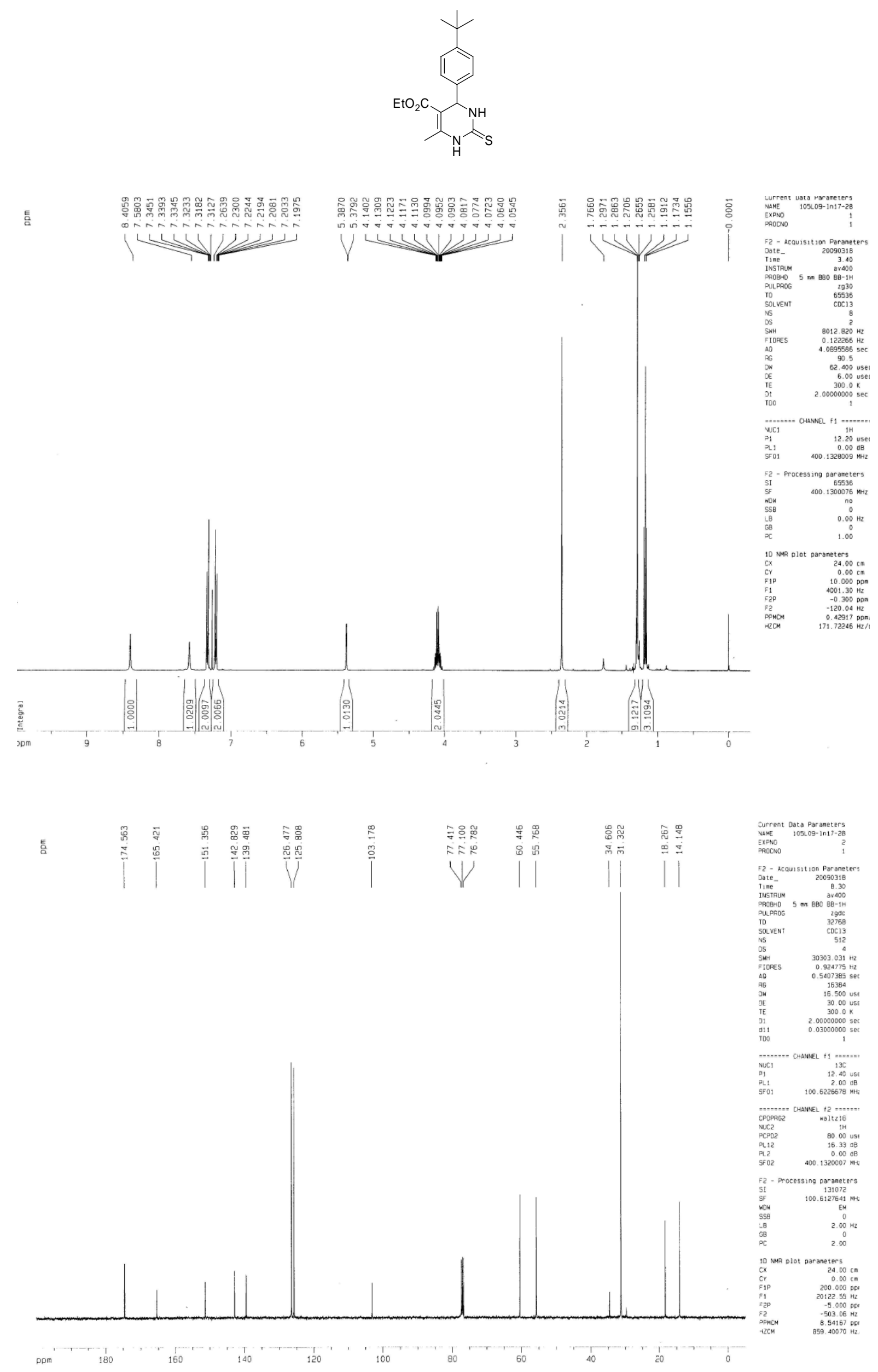


<smiles>CCC1=C(C=O)NC(=S)NC1c1cccc(F)c1</smiles>

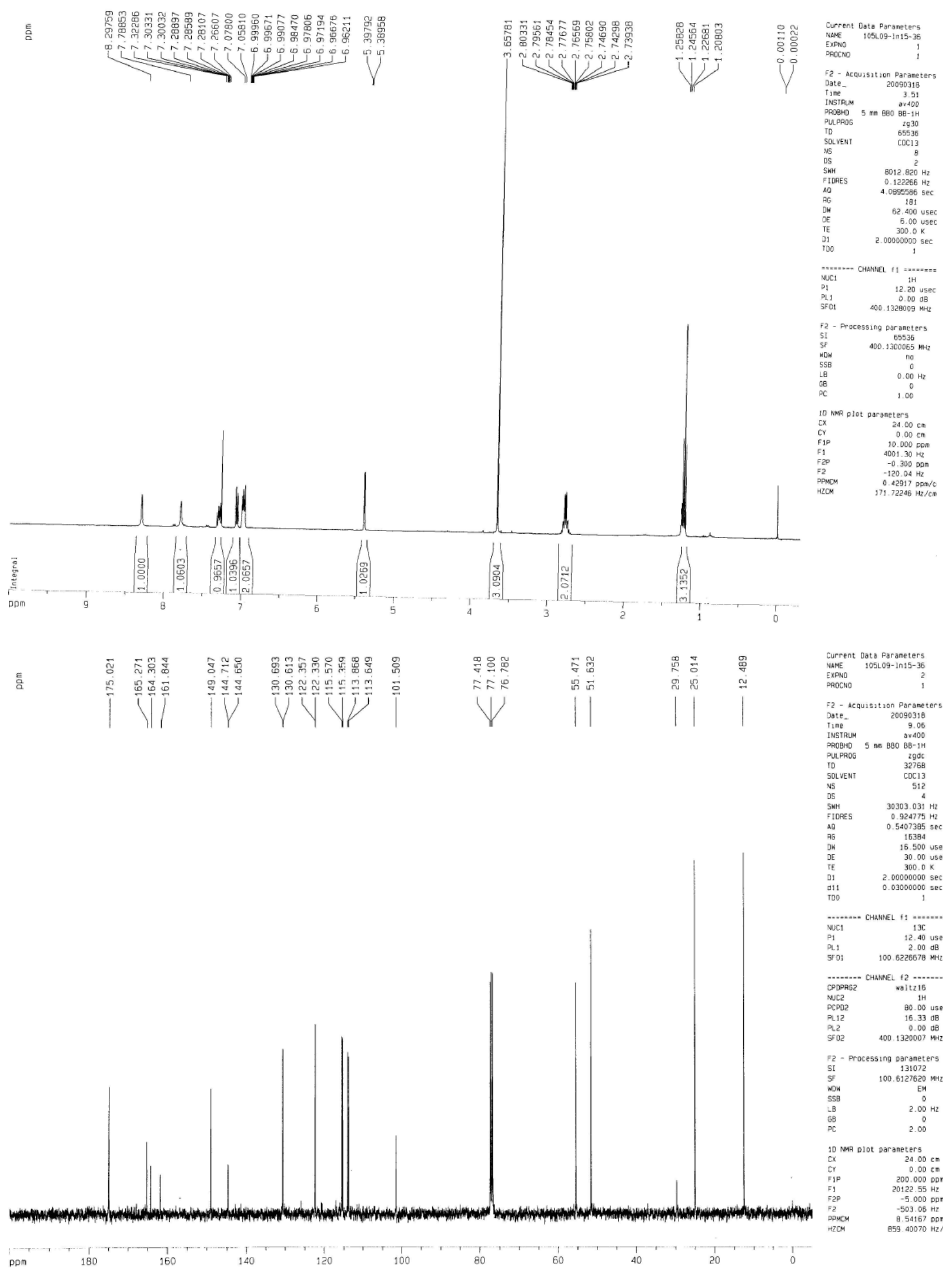



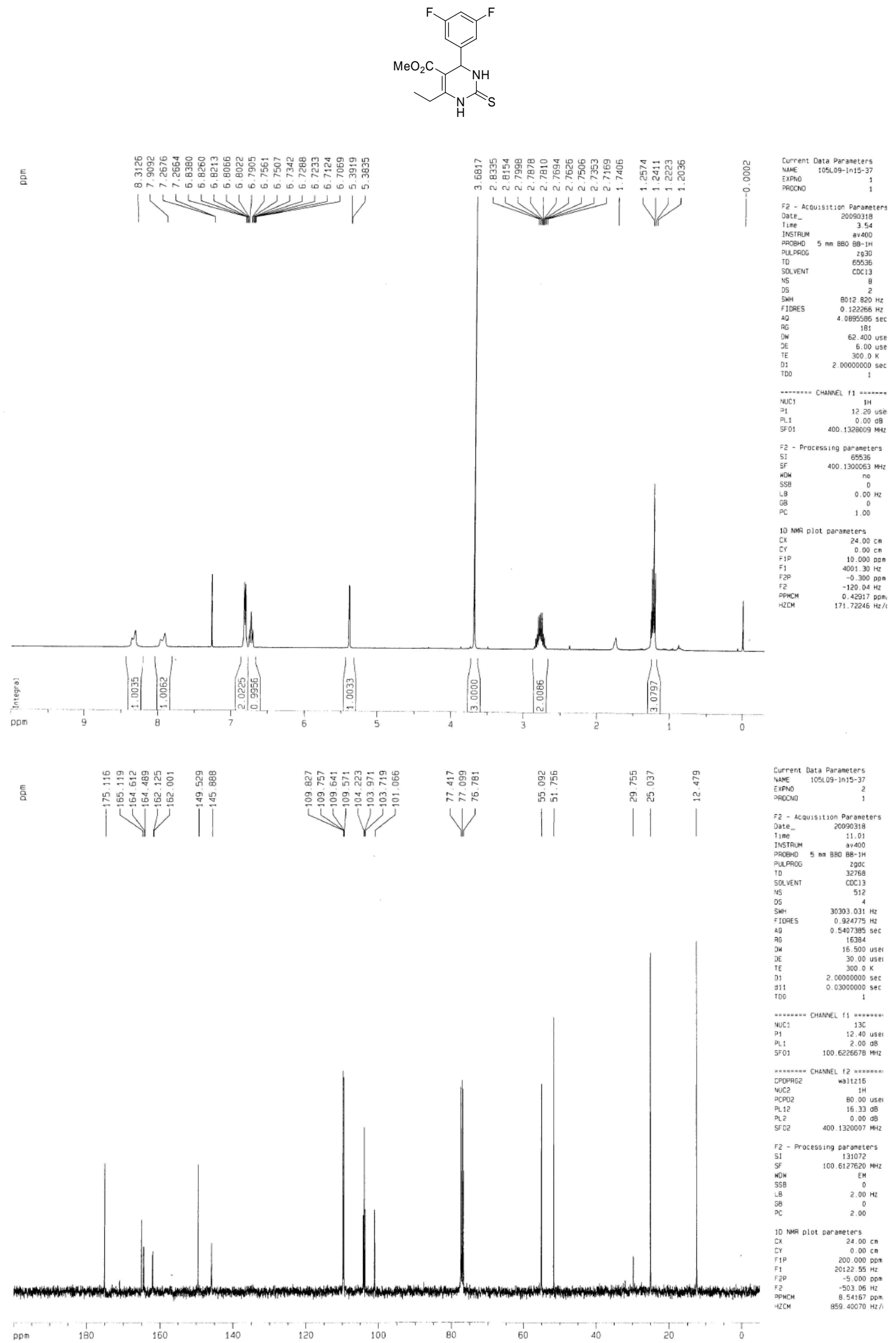

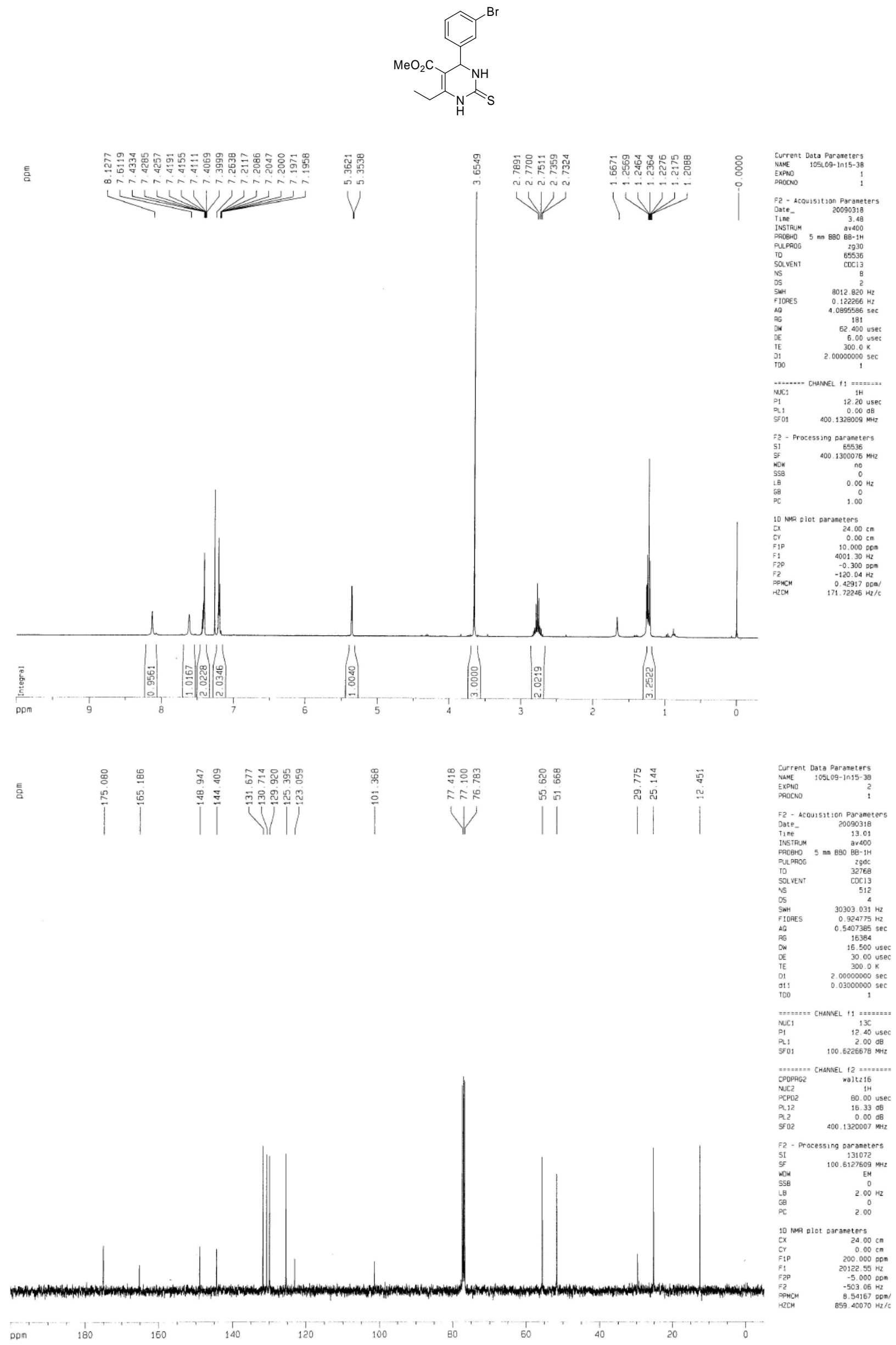

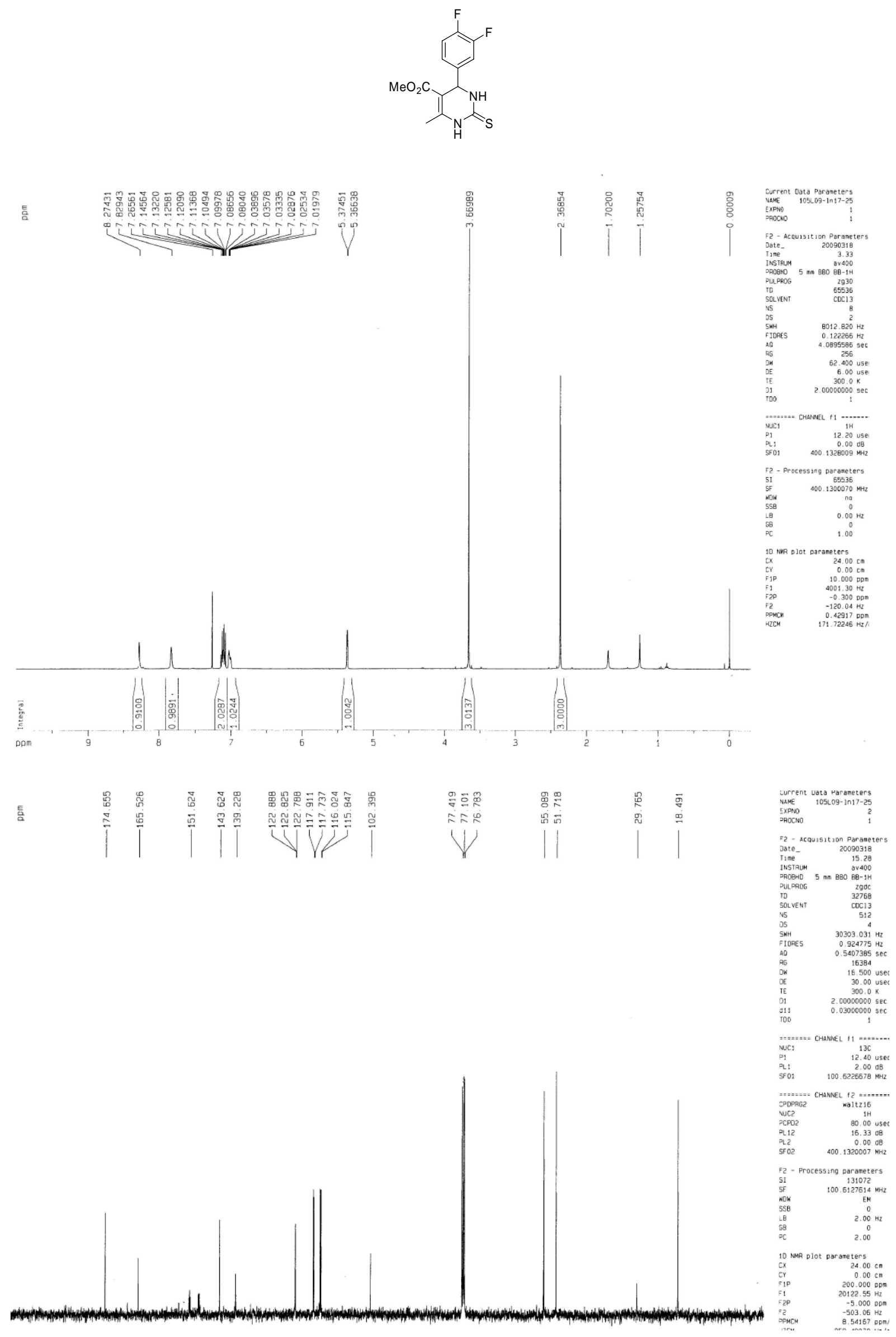

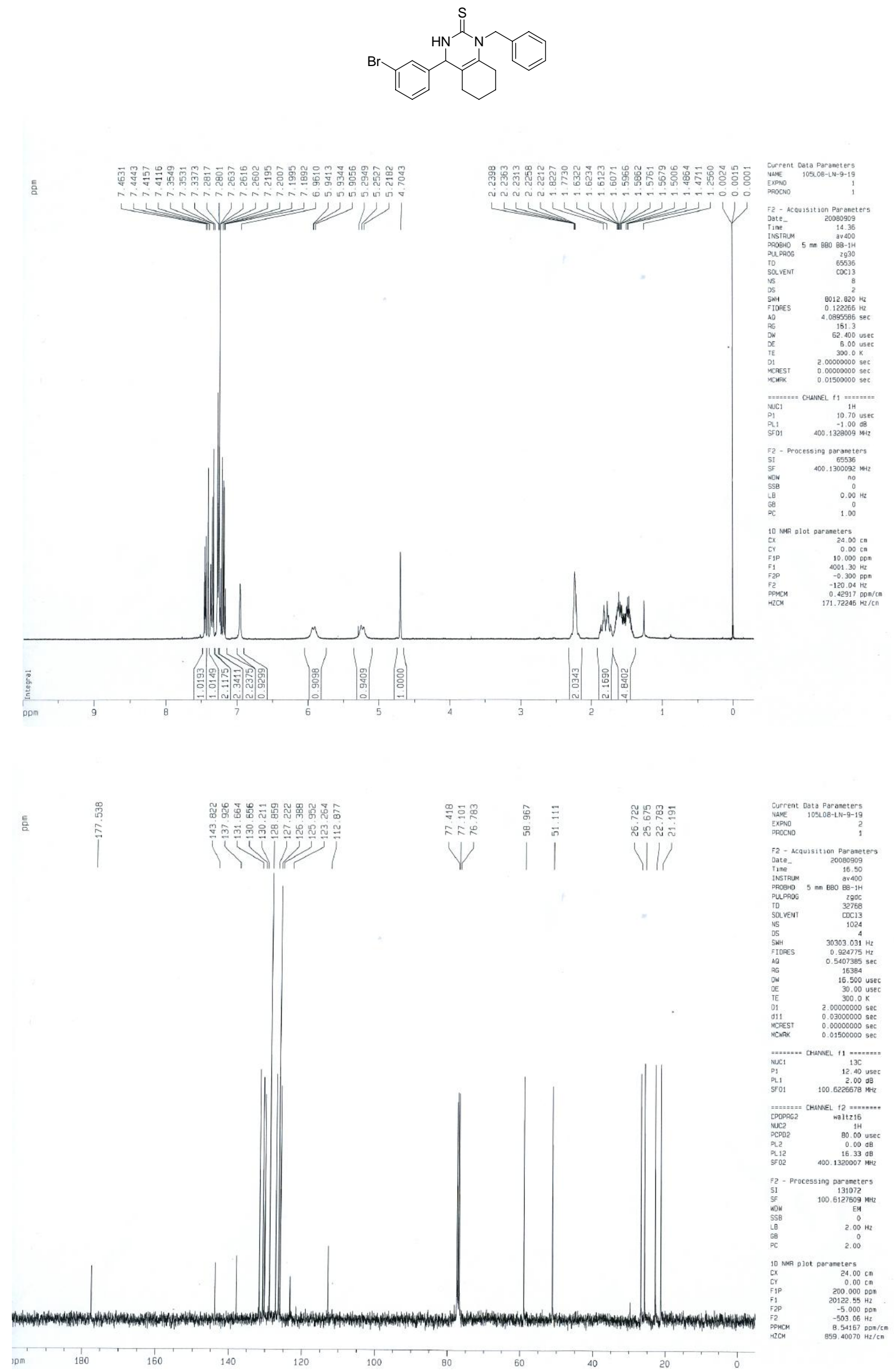

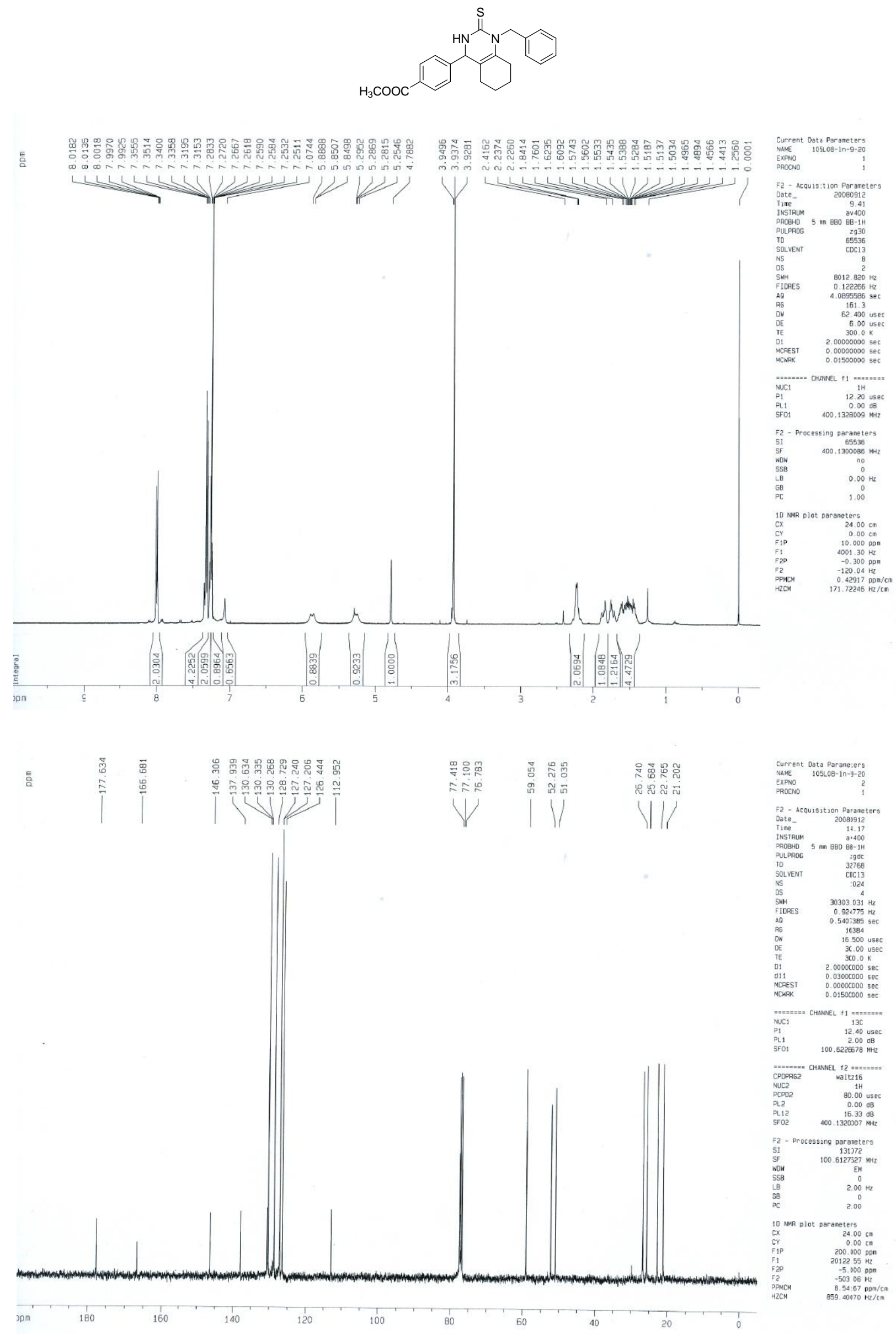

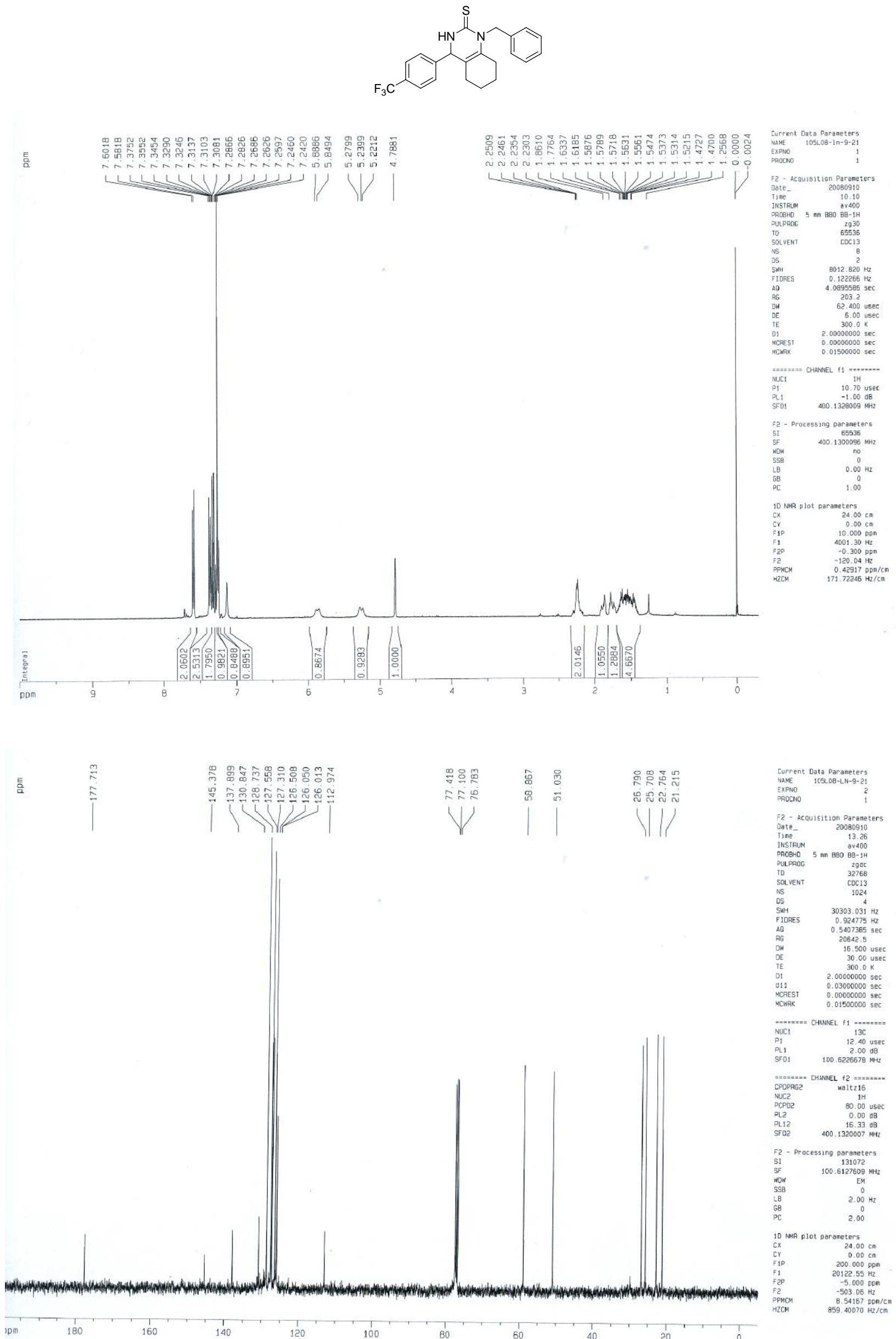

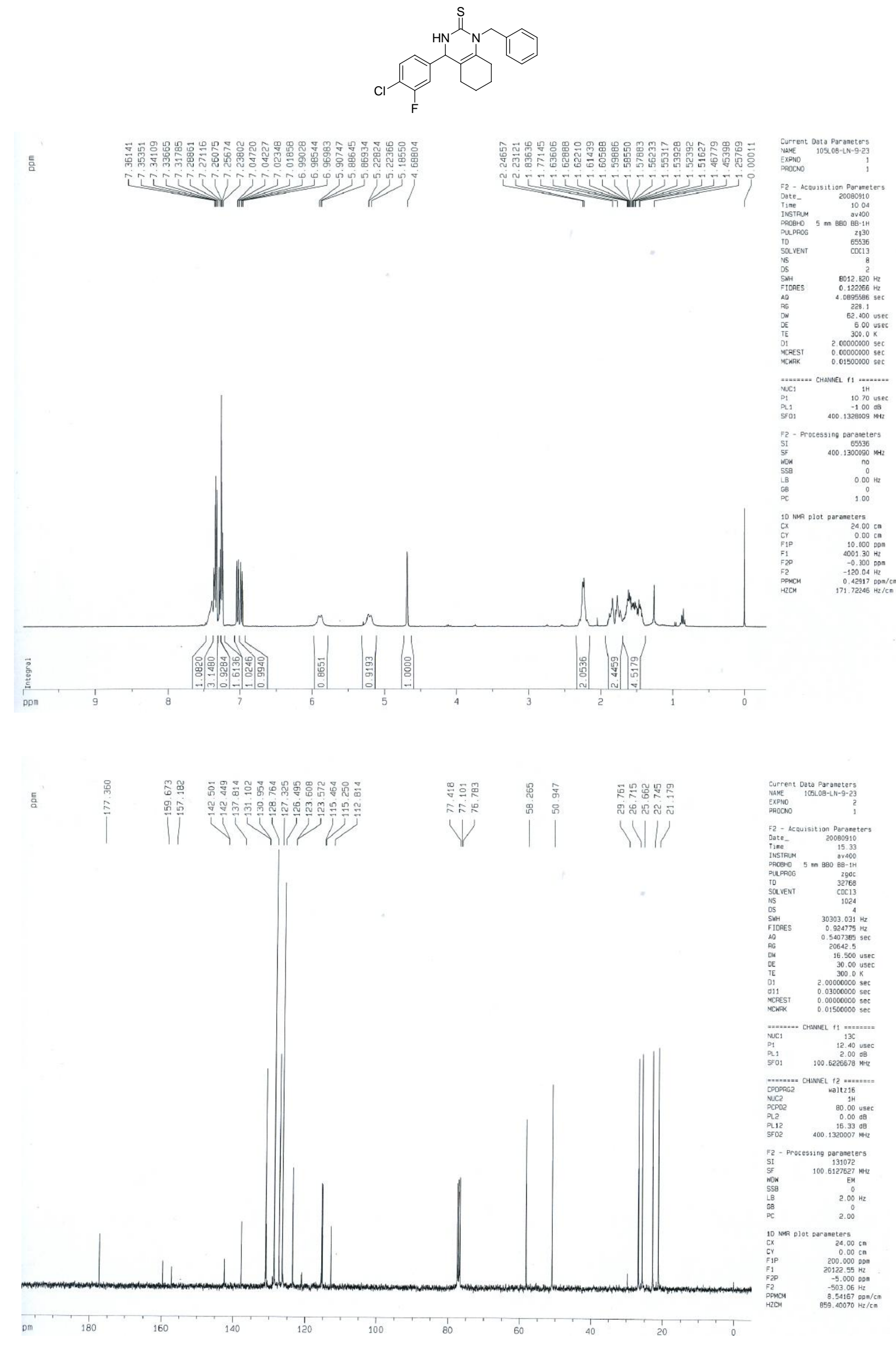


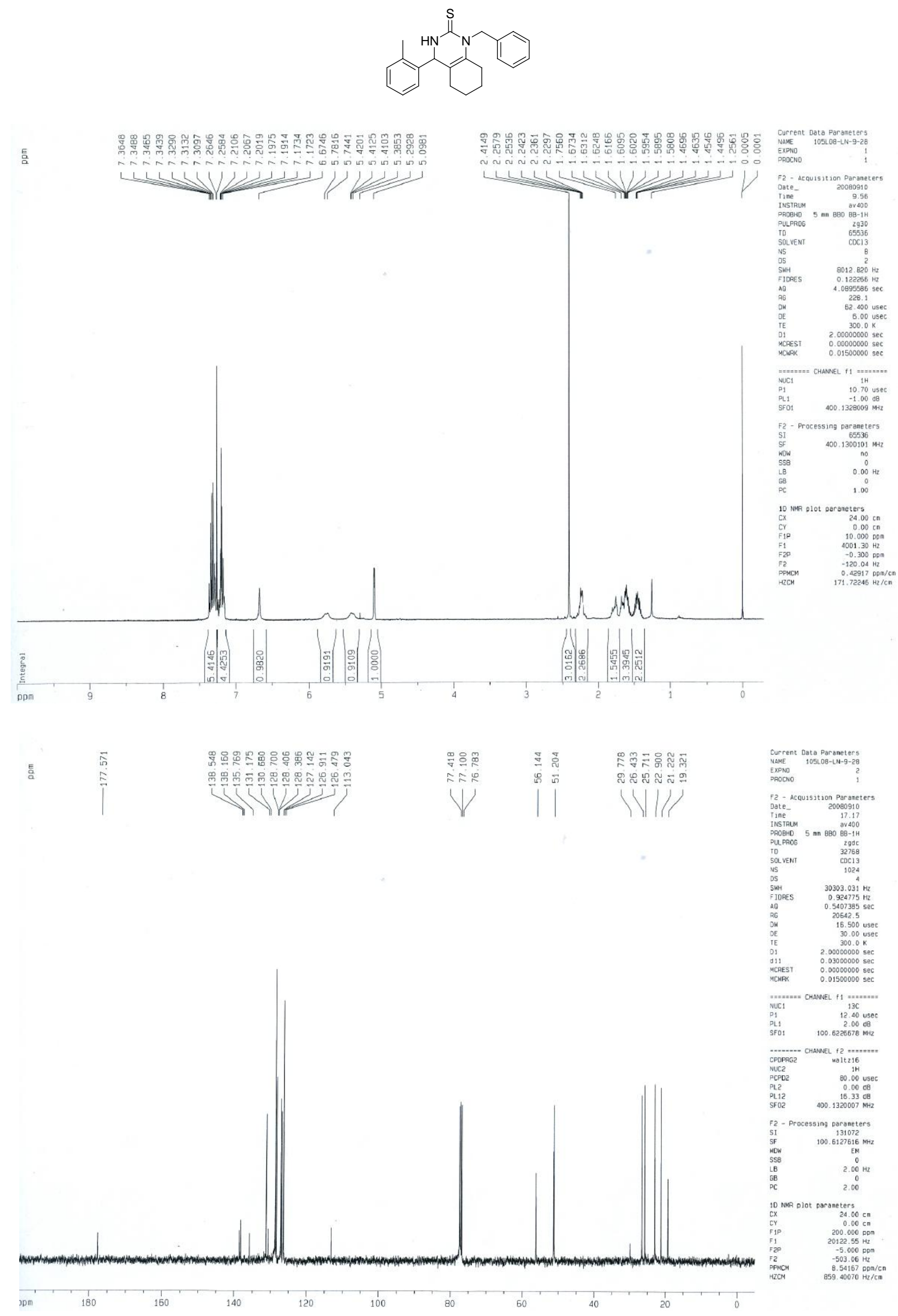




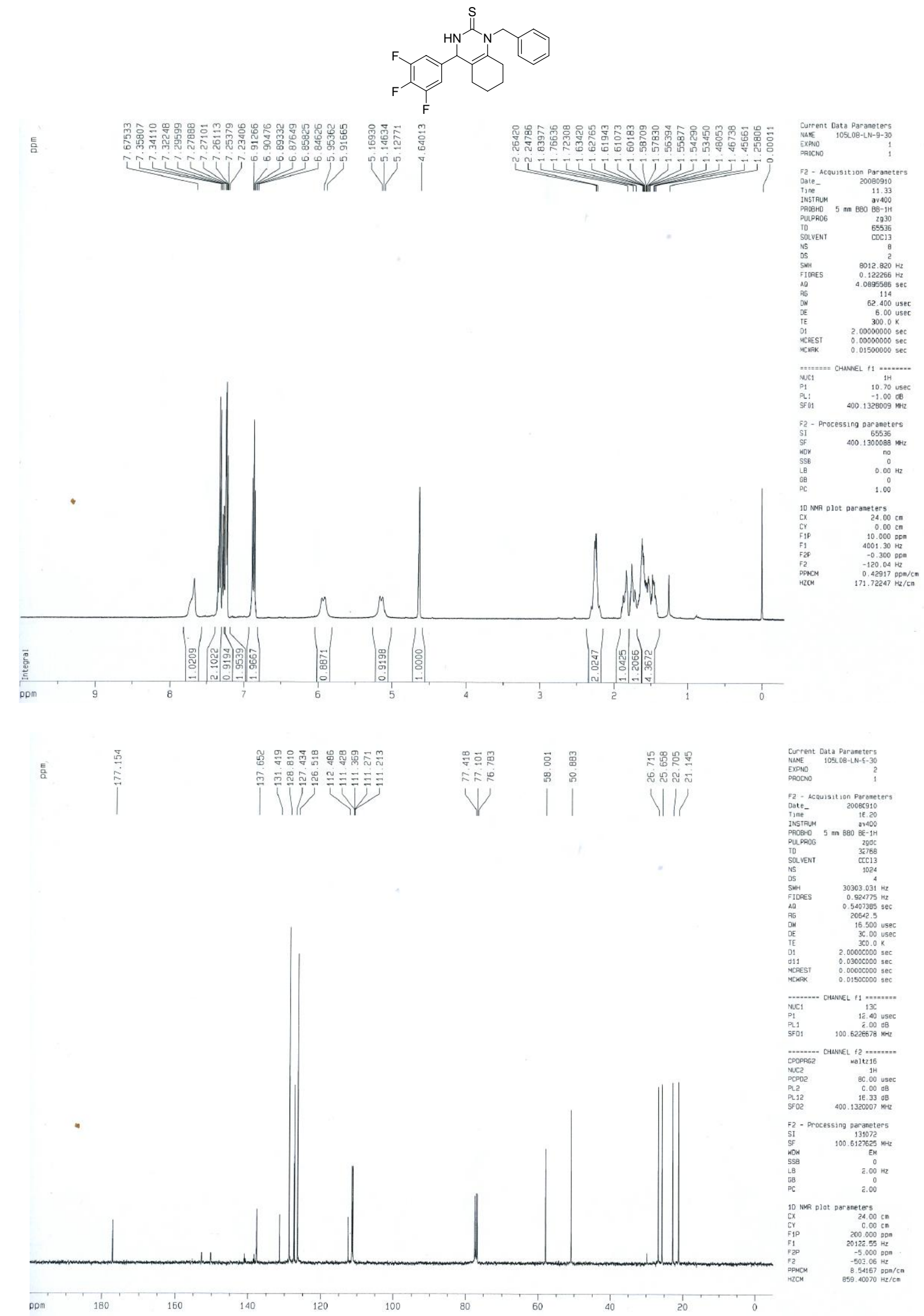




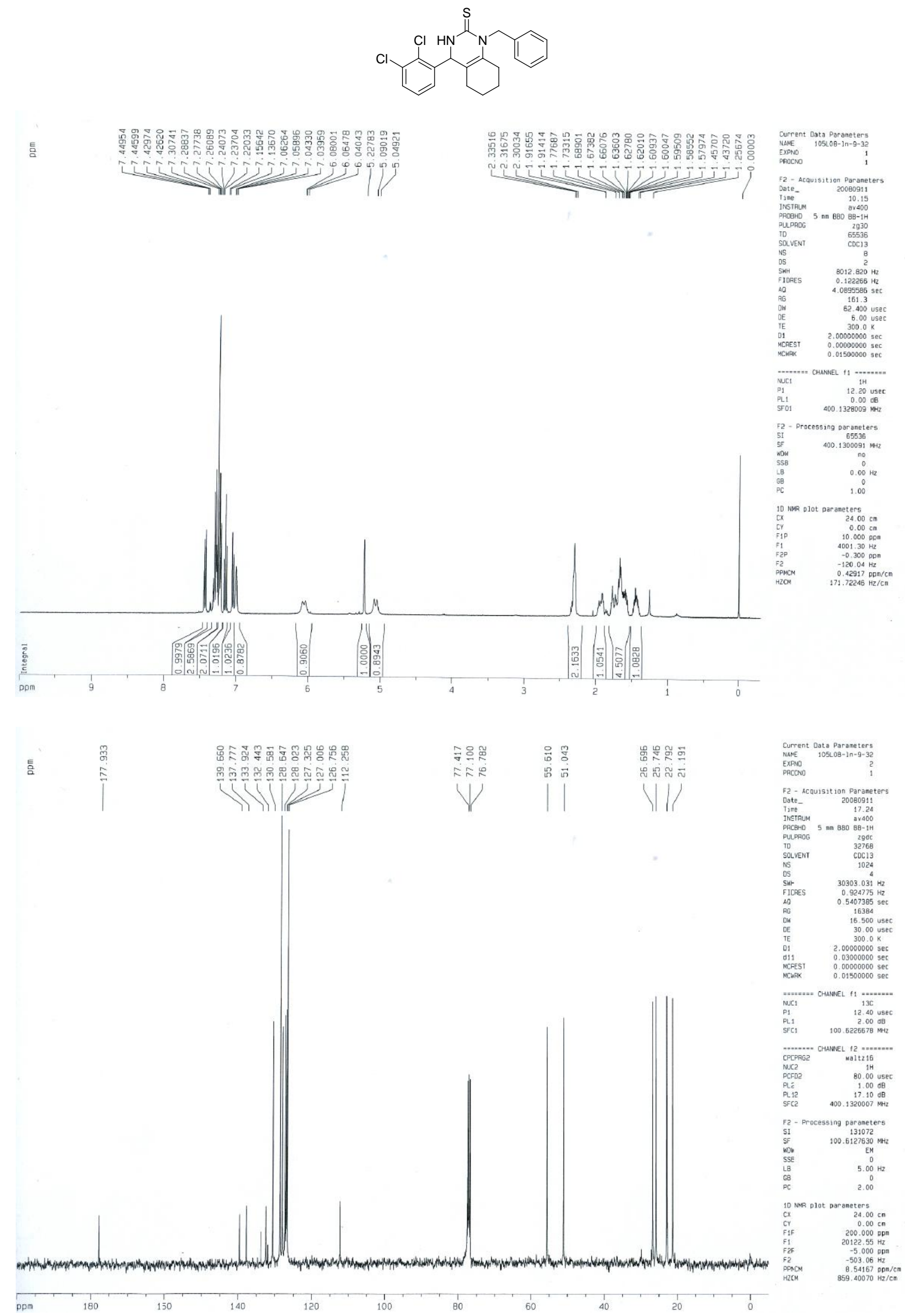




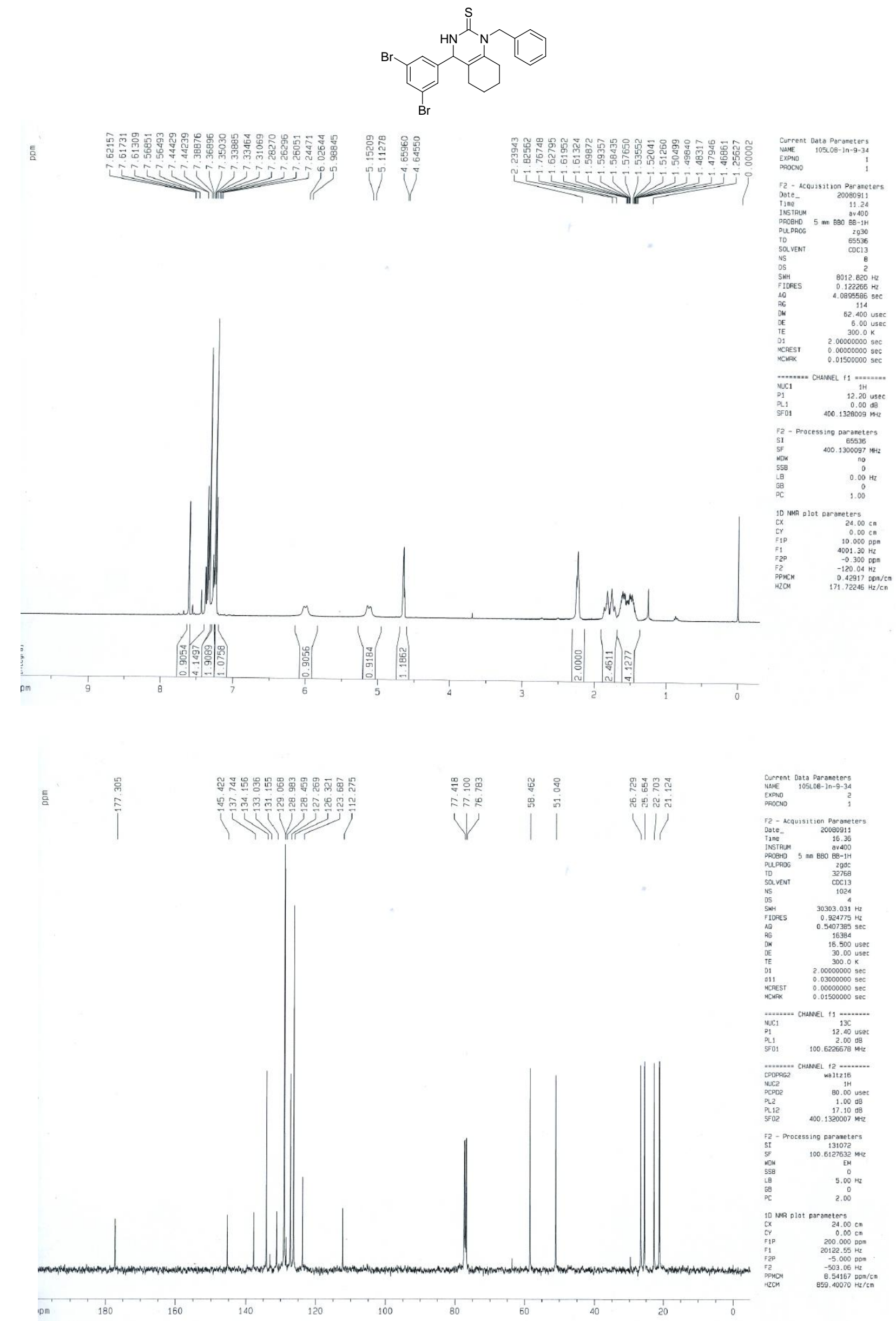




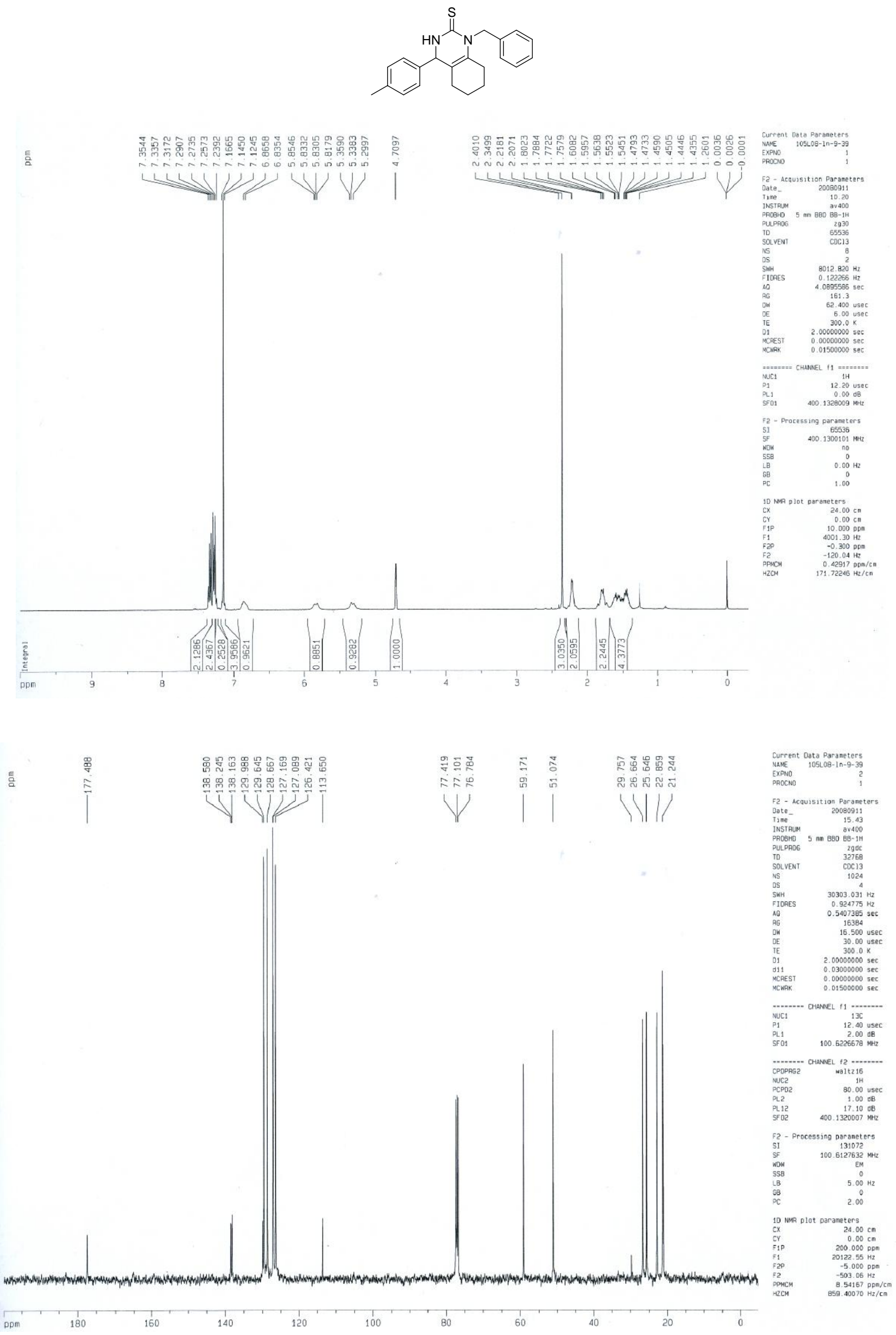



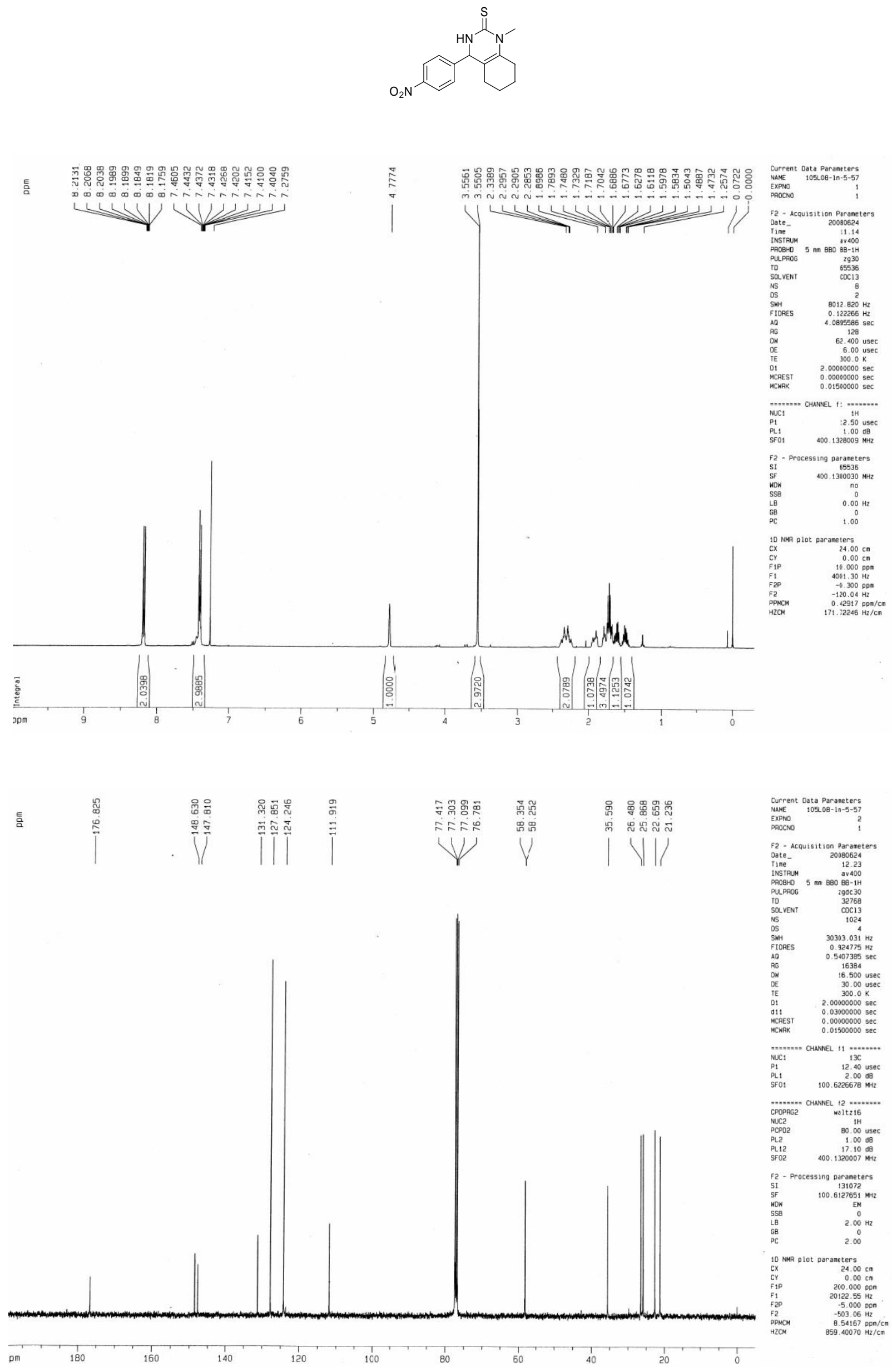


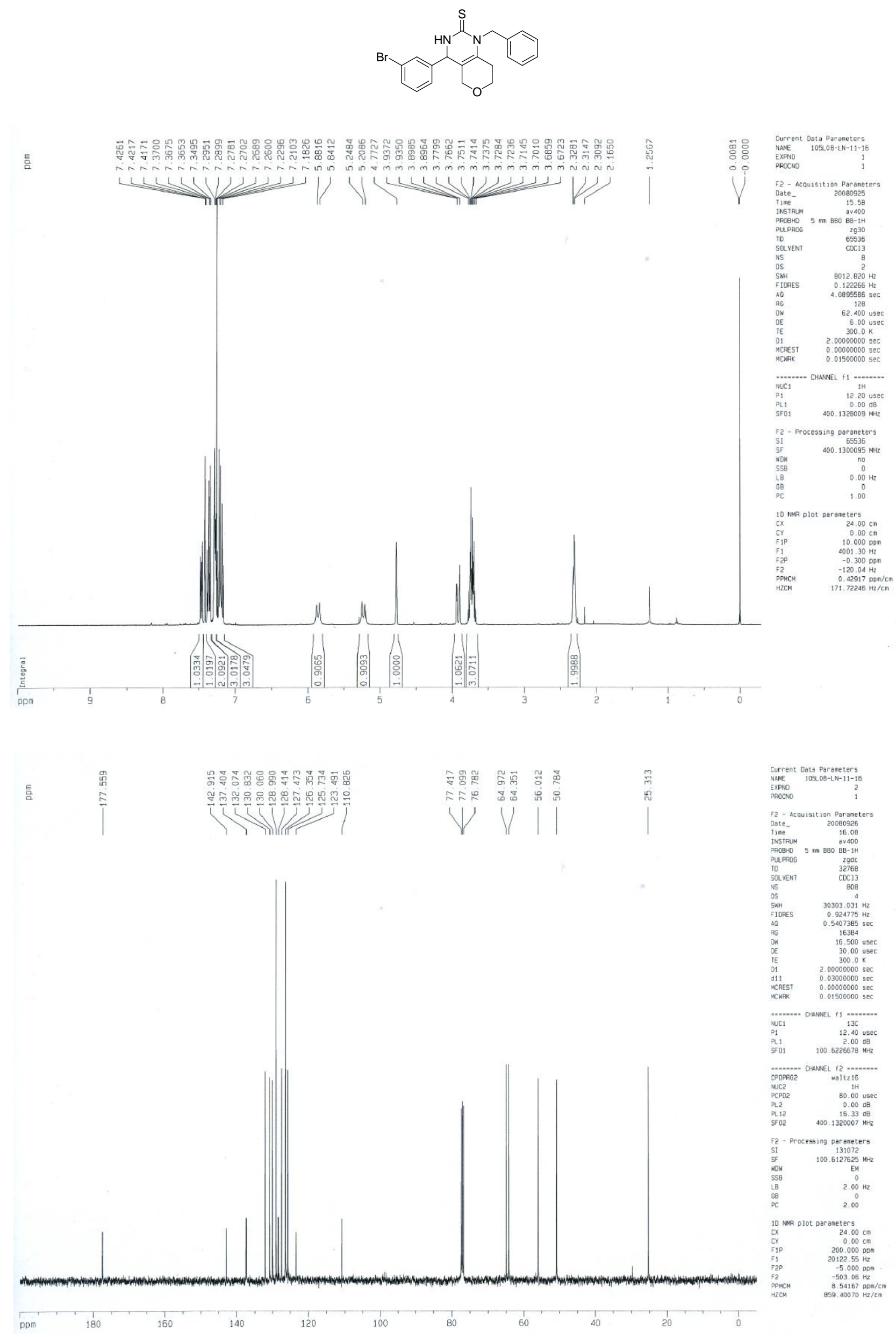



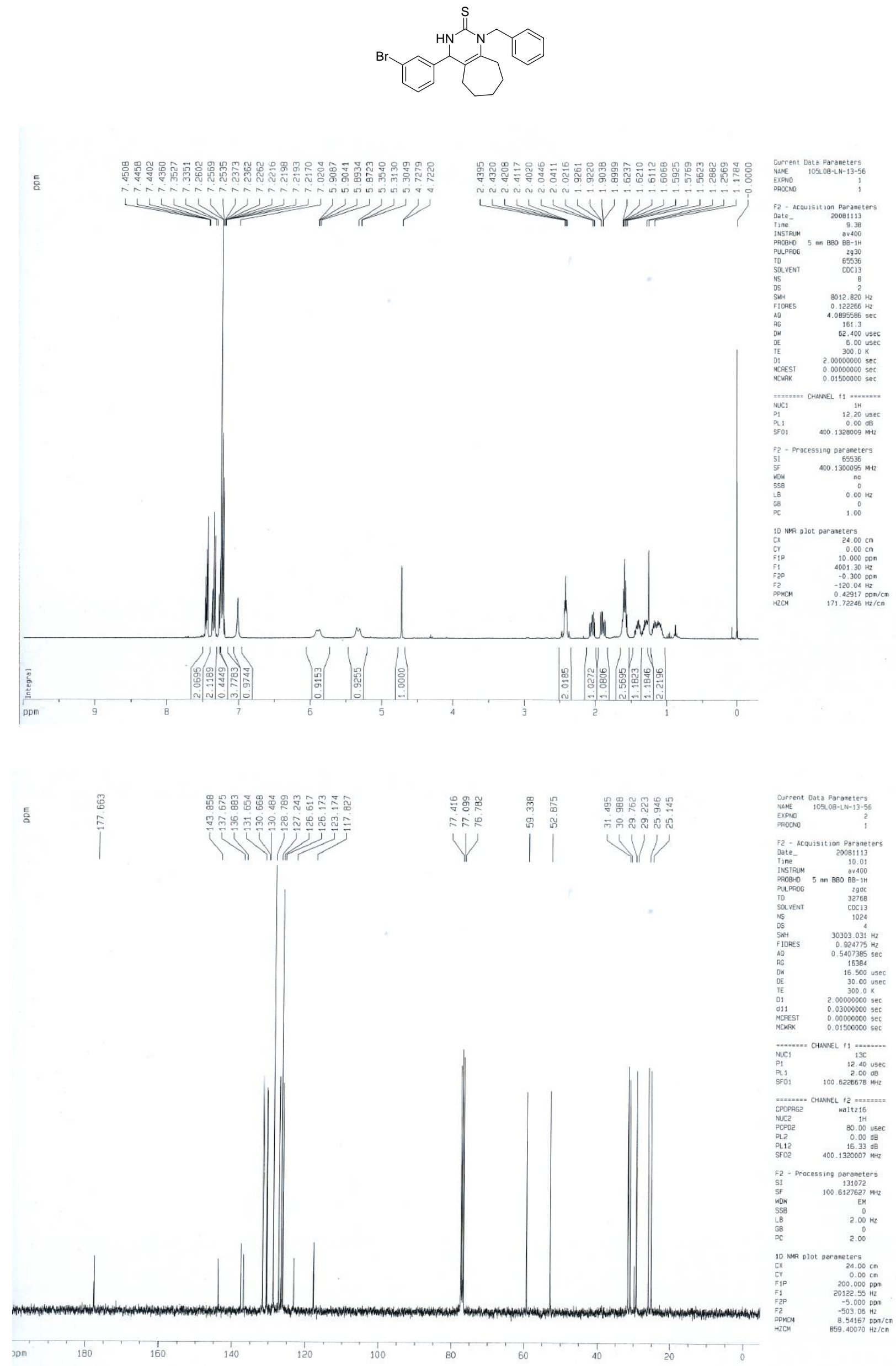


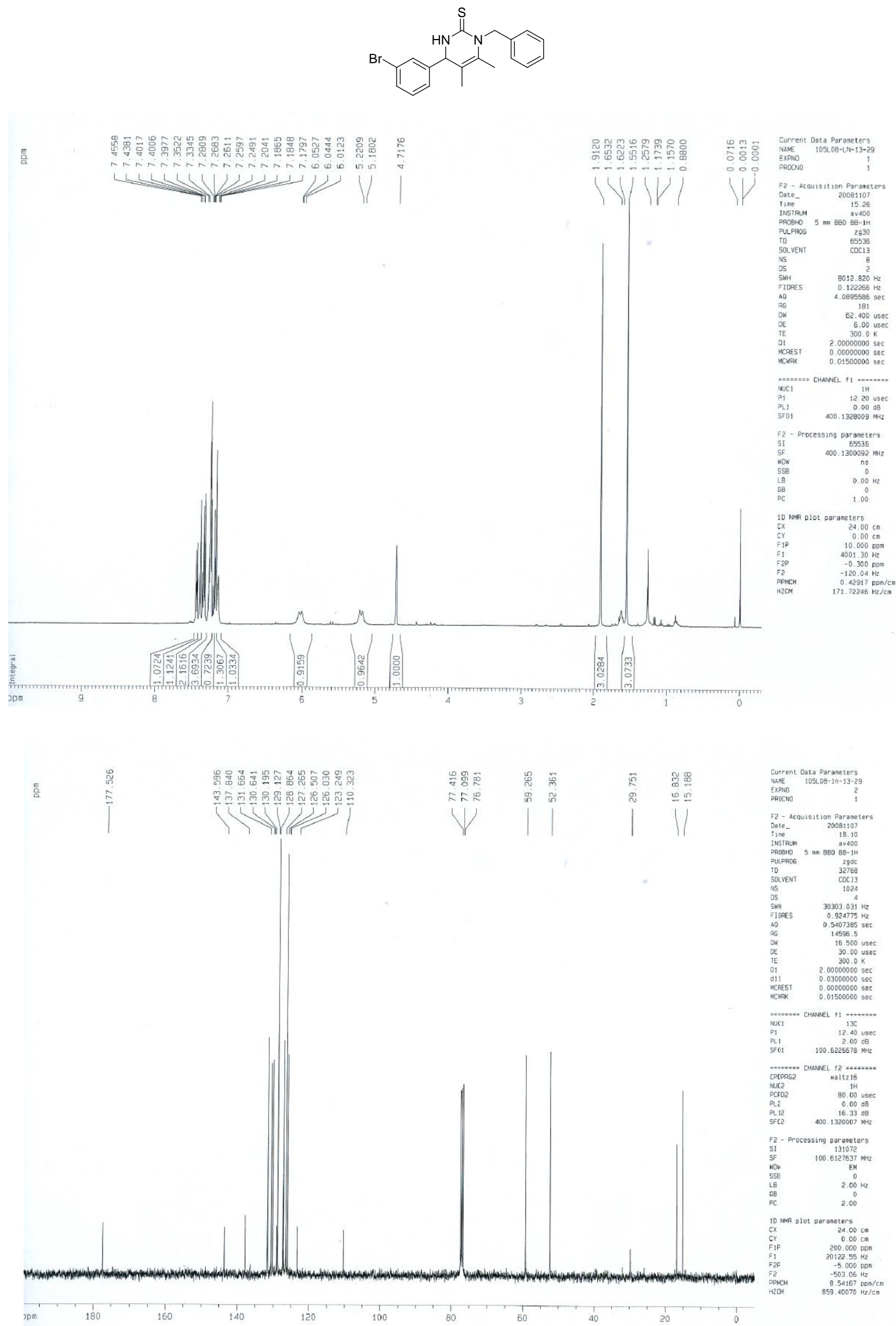



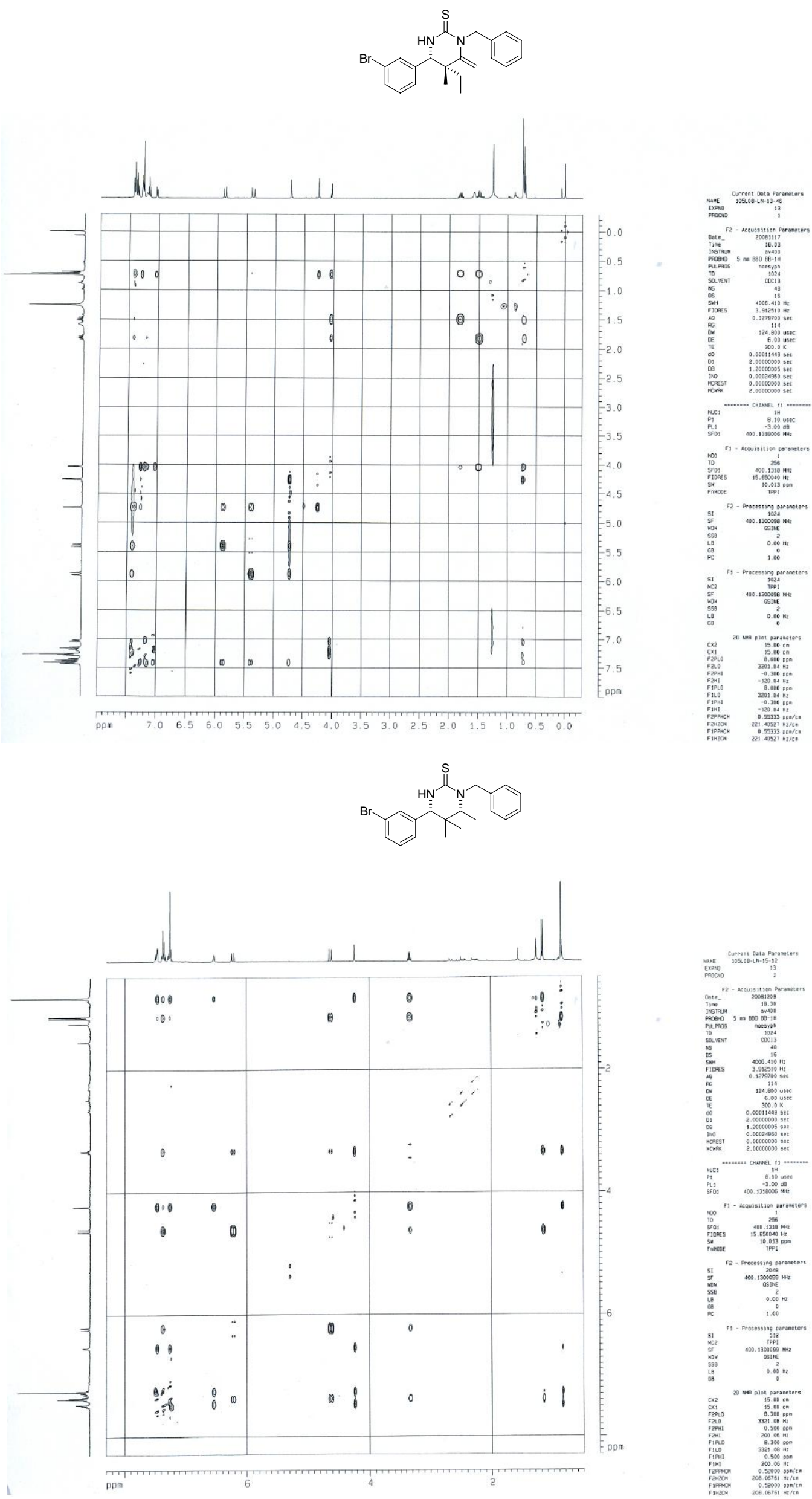


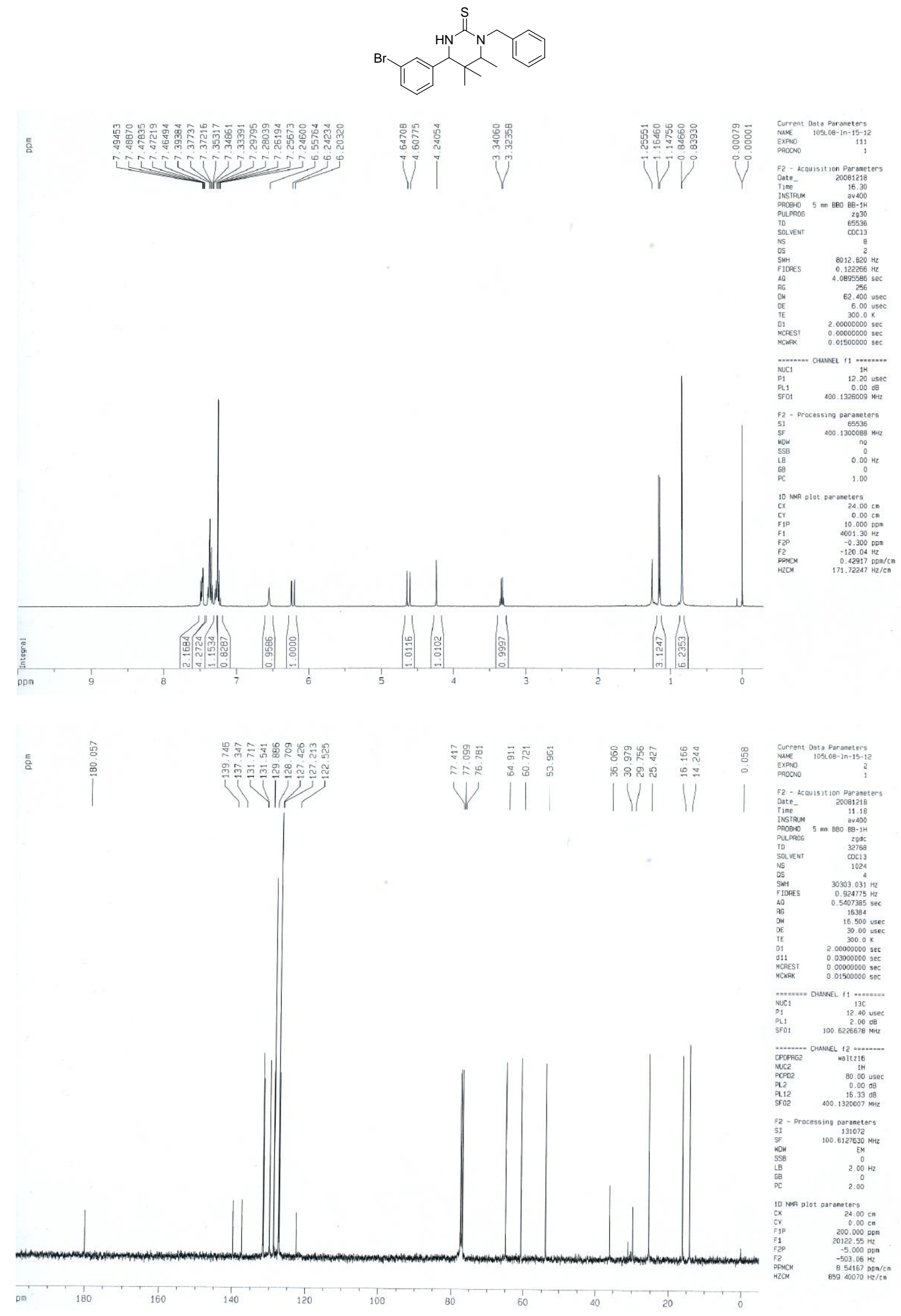




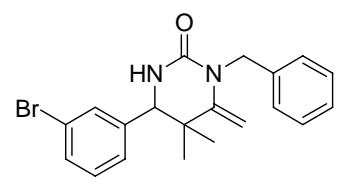
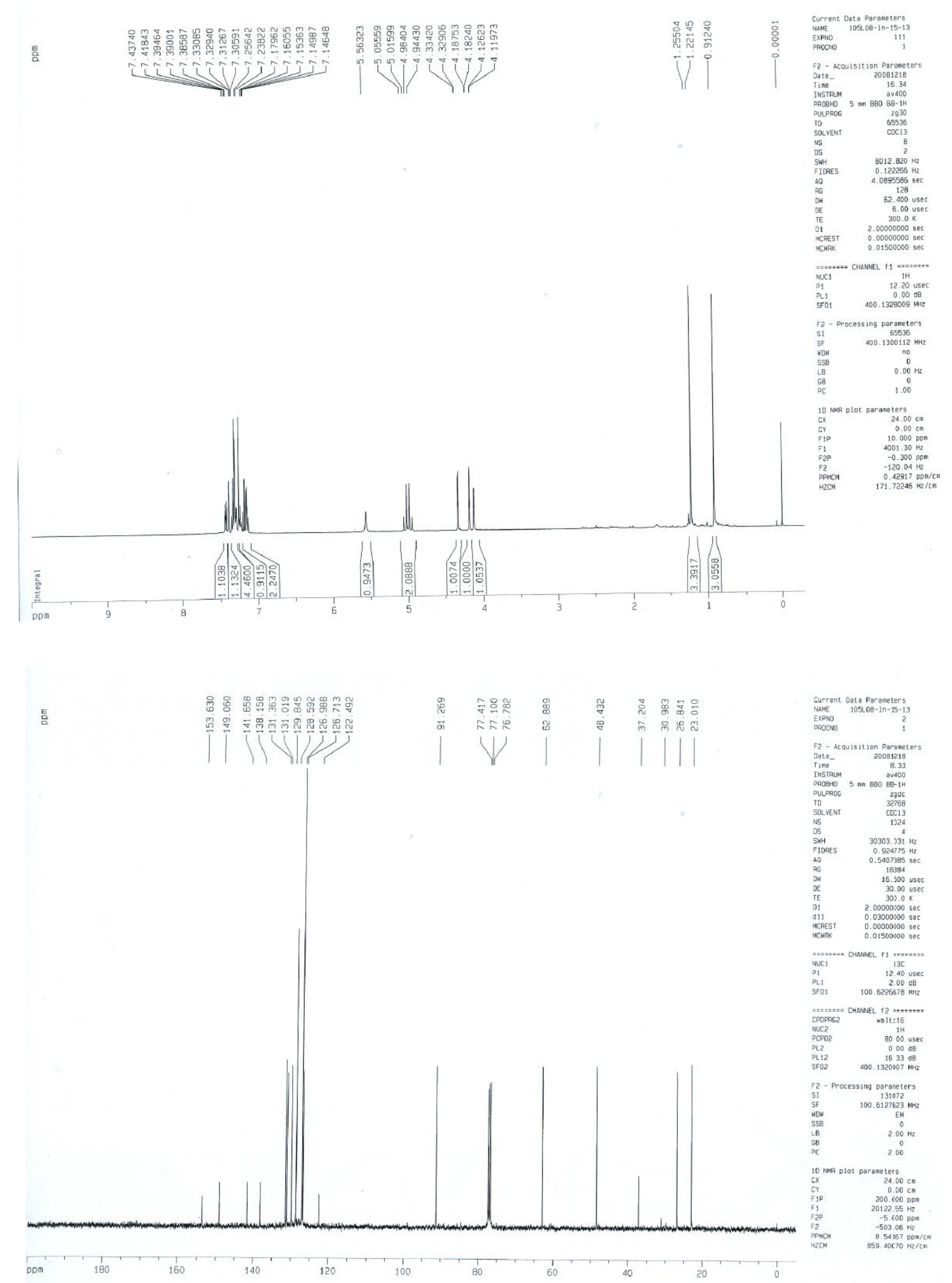


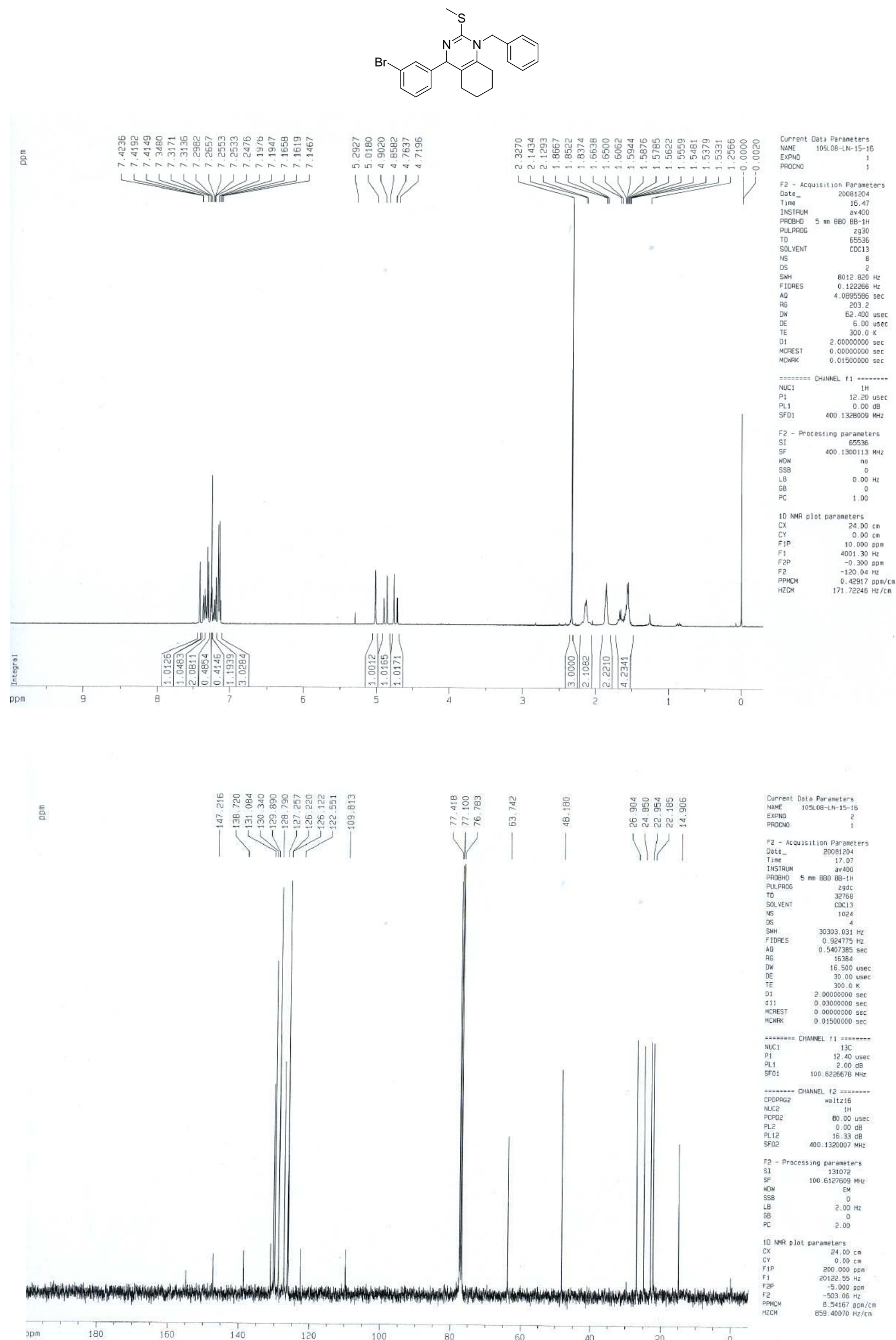




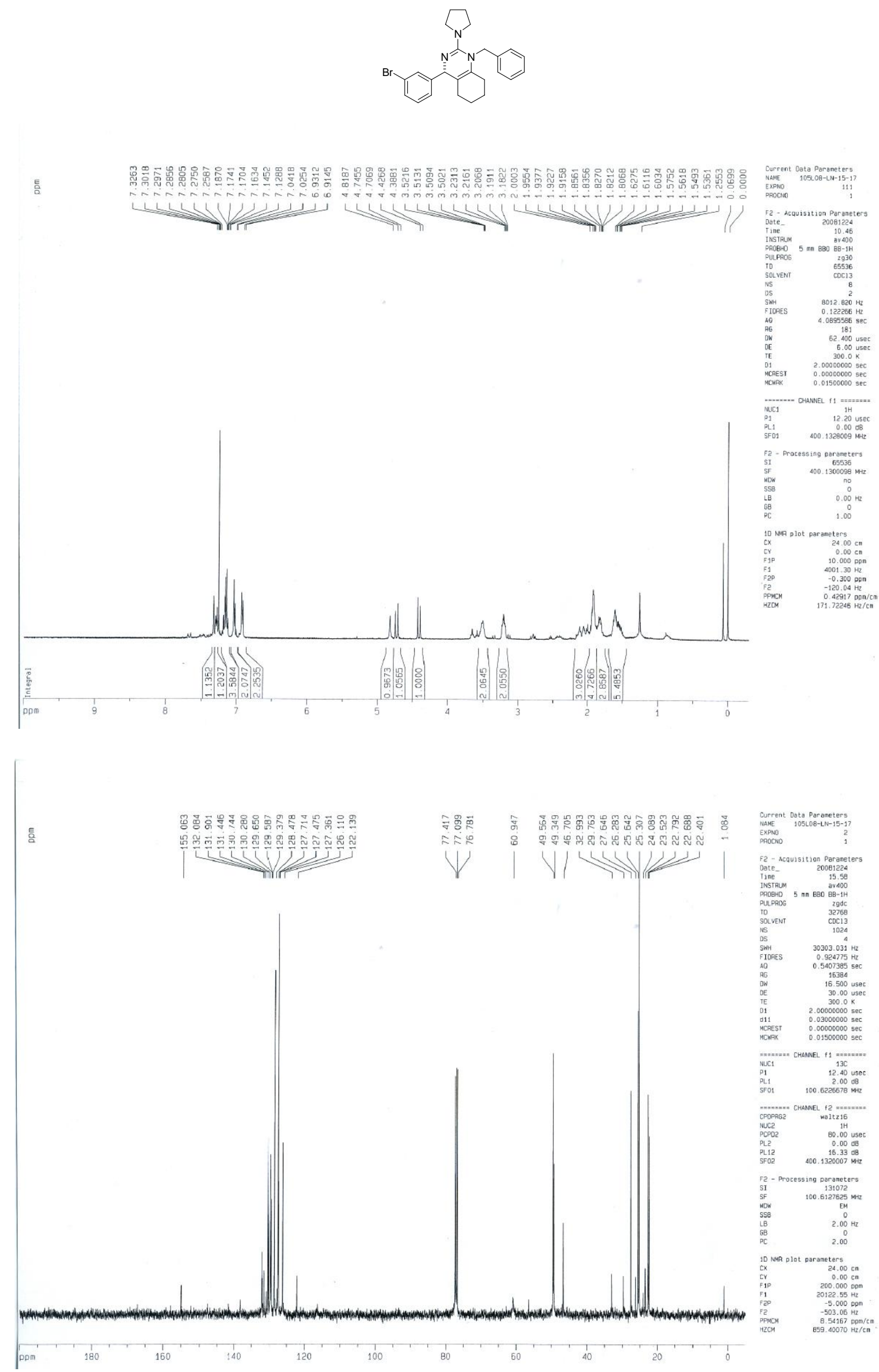



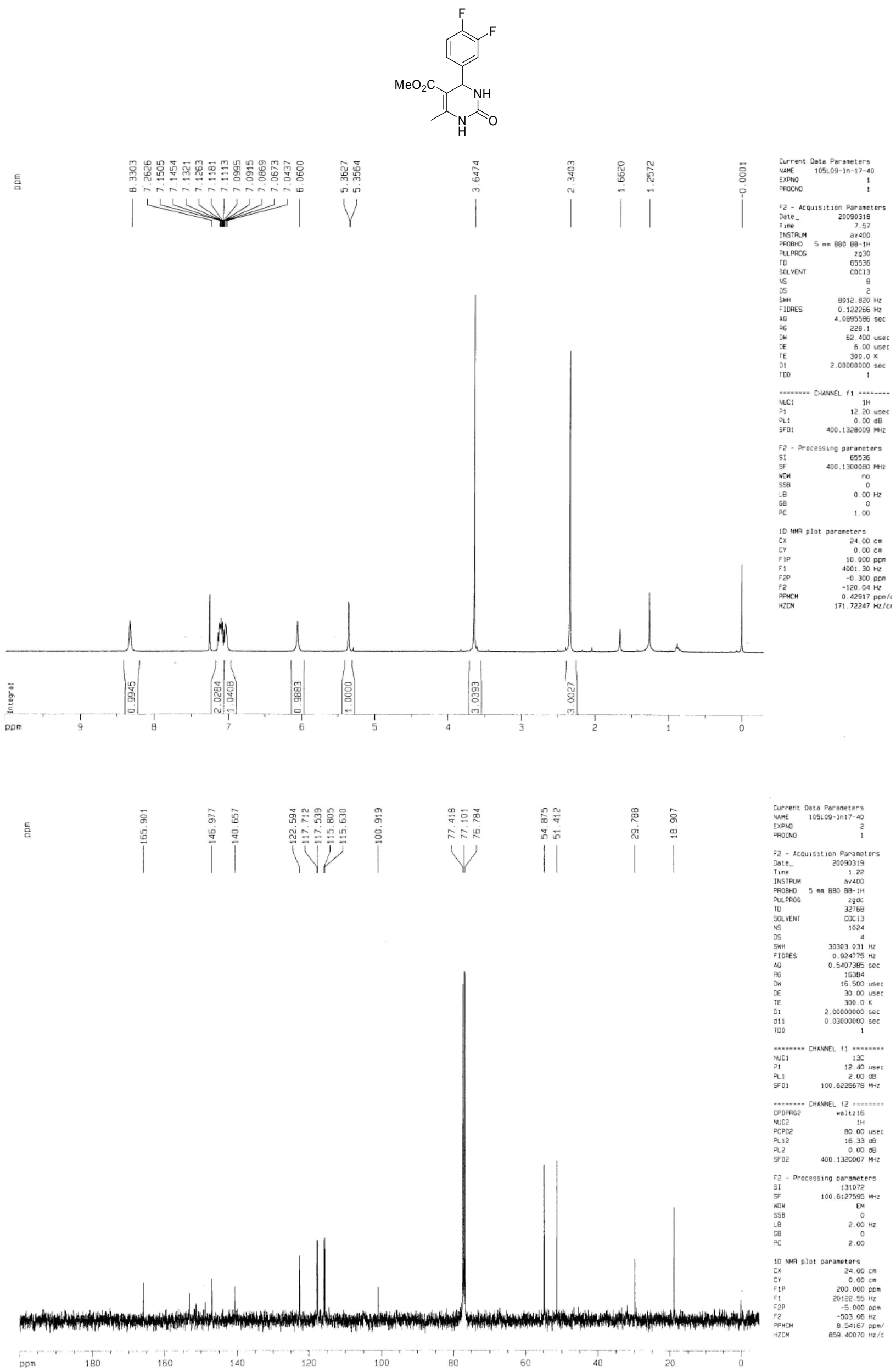


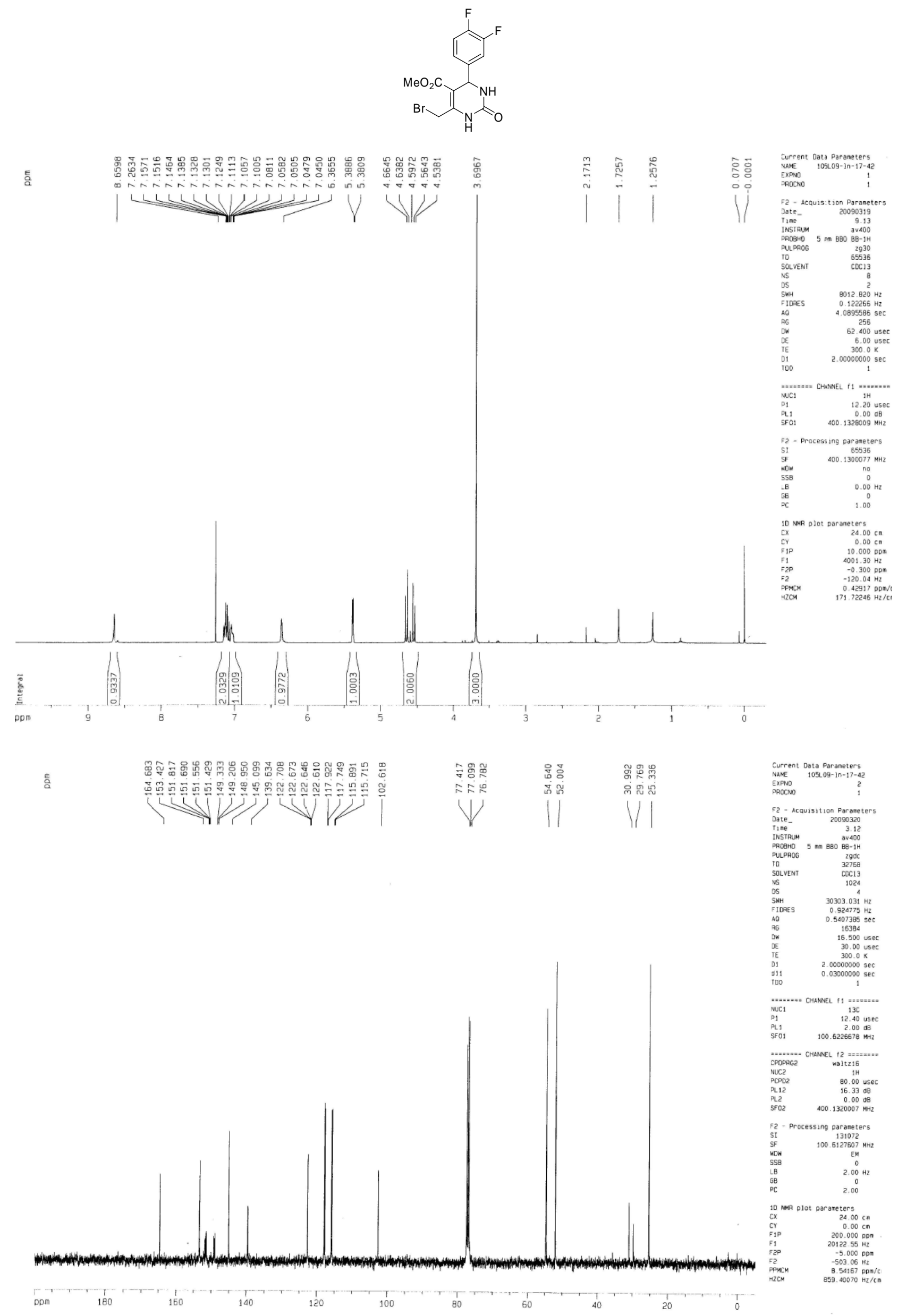



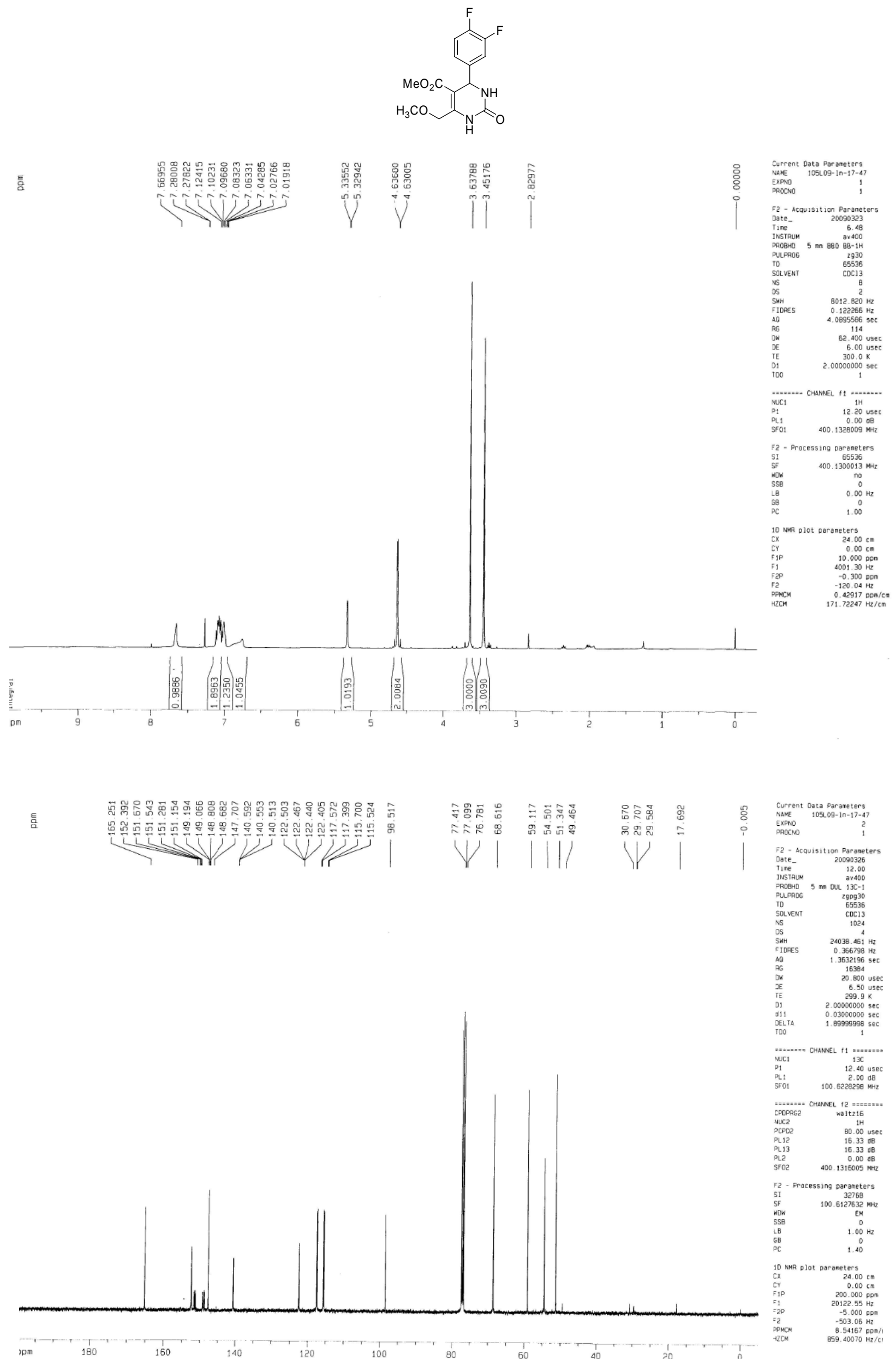